\title{
Leverage dan Kinerja Perusahaan dengan Ukuran Perusahaan sebagai Variabel Intervening
}

\author{
Muhammad Fathoni ${ }^{1}$, Fifi Swandari ${ }^{2}$ \\ ${ }^{12}$ Universitas Lambung Mangkurat \\ Email : fathoni.muh51@gmail.com
}

\begin{abstract}
This study aims to analyze the effect of leverage as an independent variable on company performance as a dependent variable with firm size as an intervening variable on non oil and gas manufacturing companies on the Indonesia Stock Exchange.

This research is a type of causality research with quantitative research. The population used in this study are all on non oil and gas manufacturing companies listed on the Indonesia Stock Exchange, while the sampling technique uses purposive sampling. The analysis technique used is path analysis. Analysis tools using the SmartPLS application with an assessment model can be done by evaluating the outside and inner models.

The results of this research showed that there was a negative and significant effect between the ratio of debt to ROA while there was a positive and significant effect between the ratio of debt to ROE. Debt ratio have a positive and significant effect on company size. Company size has a positive and significant effect on ROA and has no effect on ROE. Company size is able to fully mediate the influence between debt ratio to ROA.
\end{abstract}

Keywords: Debt Ratio, Company Size, ROA, and ROE.

\section{Abstrak}

Penelitian ini bertujuan untuk menganalisis pengaruh antara leverage sebagai variabel independen terhadap kinerja perusahaan sebagai variabel dependen dengan ukuran perusahaan sebagai variabel intervening pada perusahaan manufaktur non migas yang terdapat di Bursa Efek Indonesia.

Penelitian ini merupakan jenis penelitian kausalitas dengan pendekatan kuantitatif. Populasi yang digunakan dalam penelitian ini adalah seluruh perusahaan manufaktur non migas yang terdaftar di Bursa Efek Indonesia, adapun teknik pengambilan sampel menggunakan purposive sampling. Teknik analisis yang digunakan adalah analisis jalur (path analysis). Alat analisis menggunakan aplikasi SmartPLS dengan model evaluasi dapat dilakukan dengan menilai outer model dan inner model.

Hasil penelitian menunjukkan bahwa terdapat pengaruh negatif dan signifikan antara rasio utang terhadap ROA sedangkan terdapat pengaruh positif dan signifikan antara rasio utang terhadap ROE. Rasio utang berpengaruh positif dan signifikan terhadap ukuran perusahaan. Ukuran perusahaan berpengaruh positif dan signifikan terhadap ROA dan tidak berpengaruh terhadap ROE. Ukuran perusahaan mampu memediasi secara penuh pengaruh antara rasio utang terhadap ROA.

Kata Kunci: Rasio utang, ukuran perusahaan, ROA, dan ROE.

(C) 2020 Jurnal Riset Inspirasi Manajemen dan Kewirausahaan

\section{PENDAHULUAN}

Indonesia merupakan negara dengan penduduk yang besar sehingga laju pertumbuhan ekonomi di Indonesia masih didominasi dari daya beli masyarakat pada sektor konsumsi dan belanja pemerintah. Indonesia tahun 2018 mencatatkan tingkat pertumbuhan ekonomi pada triwulan 4 sebesar $5.18 \%$ lebih rendah $0.01 \%$ dari tahun 2017 yang mencatatkan tingkat pertumbuhan ekonomi pada triwulan 4 sebesar $5.19 \%$. Manufaktur atau industri pengolahan menjadi salah satu sektor yang memberikan kontribusi yang besar dalam pertumbuhan PDB Indonesia. Industri manufaktur pada sektor makan dan minuman masih mencatatkan kinerja tertinggi dalam kontribusinya terhadap PDB Indonesia dibanding sektor lainnya dengan pencapaian kinerja diatas $5 \%$ (www.bps.go.id).

Kinerja perusahaan dapat memberikan gambaran mengenai kondisi perusahaan saat ini maupun prospek dimasa depan. Kondisi kinerja perusahaan dapat dilihat dari laporan keuangan perusahaan. Ada beberapa cara dalam mengukur kinerja perusahaan salah satunya dengan melihat tingkat profitabilitasnya. Analisis rasio keuangan yang digunakan dalam penelitian ini adalah rasio profitabilitas dengan melihat ROA dan ROE. Kinerja perusahaan dapat dipengaruhi oleh 
beberapa faktor yaitu Total Debt, Size, Age, Institutional Ownership, Liquidity, Tangibility, Aset Turnover dan Growht (William \& Sanjaya, 2017). Leverage biasa disebut sebagai pengungkit, leverage digunakan untuk meningkatkan tingkat keuntungan yang diharapkan. Ada dua jenis leverage yaitu operating leverage dan financial leverage.

Financial Leverage merupakan implementasi kebijakan perusahaan yang berkaitan dengan masalah pendanaan, dan berkenaan dengan penggunaan utang oleh perusahaan (Sudiyatno, 2010). Penggunaan utang untuk membiayai kegiatan perusahaan melalui dana dari kreditur akan meningkatkan financial leverage. Ukuran perusahaan juga menjadi faktor yang dapat mempengaruhi kinerja perusahaan. Ukuran perusahaan dapat diukur dengan log natural terhadap total aset yang dimiliki perusahaan. Menurut Zeitun \& Tian (2007) ukuran perusahaan yang diukur melalui log natural terhadap total aset memiliki pengaruh positif dan signifikan terhadap kinerja perusahaan. Teori trade-off menjelaskan perusahaan dapat dikatakan mencapai titik maksimum dalam penggunaan struktur modal apabila perusahaan mampu mendapatkan laba yang lebih banyak dari utang perusahaan dengan memanfaatkan utang sebaik mungkin untuk menghindari risiko kebangkrutan akibat utang perusahaan (Hanafi, 2016, p. 309). Teori pecking order bisa menjelaskan bahwa perusahaan yang mempunyai tingkat keuntungan yang tinggi justru mempunyai tingkat utang yang lebih kecil (Hanafi, 2016, p. 314).

Penelitian tentang pengaruh leverage terhadap kinerja perusahaan telah banyak diteliti dan memiliki hasil yang berbeda sehingga masih dapat diteliti. Khan (2012), Tifow \& Sayilir (2015) hasil penelitian bahwa leverage yang diukur dengan rasio utang LTDTA dan STDTA berpengaruh negatif dan signifikan terhadap ROA. Azeez (2015), Aziz \& Abbas (2019) hasil penelitian bahwa leverage tidak memiliki pengaruh signifikan dengan kinerja perusahaan melalui rasio ROA. Tifow \& Sayilir (2015), Bokhari \& Khan (2013) menemukan leverage memiliki hubungan negatif dan signifikan terhadap kinerja perusahaan melalui rasio ROE. Hasan, et al (2014) tidak menemukan hubungan yang signifikan antara ROE dan struktur modal (Leverage). Hasan, et al (2014), Khan (2012), Tifow \& Sayilir (2015), Imadudin, et al (2014) mengatakan bahwa ukuran perusahaan tidak memiliki pengaruh yang signifikan terhadap kinerja perusahaan secara statistik. Berbeda dengan hasil penelitian yang menemukan bahwa ukuran perusahaan berpengaruh signifikan dan positif terhadap kinerja perusahaan Aziz \& Abbas (2019), Bokhari \& Khan (2013).

\section{KAJIAN LITERATUR}

Penelitian ini menggunakan teori struktur modal Trade-Off dan Pecking Order sebagai grand theory untuk mendasari penelitian ini.

Teori trade-off menjelaskan perusahaan dapat dikatakan mencapai titik maksimum dalam penggunaan struktur modal apabila perusahaan mampu mendapatkan laba yang lebih banyak dari utang perusahaan dengan memanfaatkan utang sebaik mungkin untuk menghindari risiko kebangkrutan akibat utang perusahaan (Hanafi, 2016, p. 309).

Teori pecking order tidak mengindikasikan target struktur modal tetapi teori ini menjelaskan urut-urutan pendanaan bahwa manajer keuangan tidak memperhitungkan tingkat utang yang optimal tetapi kebutuhan dana ditentukan oleh kebutuhan investasi (Hanafi, 2016, p. 314).

Leverage biasa disebut sebagai pengungkit, ada dua jenis leverage yaitu Operating Leverage dan Financial Leverage. Financial Leverage merupakan implementasi kebijakan perusahaan yang berkaitan dengan masalah pendanaan, dan berkenaan dengan penggunaan utang oleh perusahaan (Sudiyatno, 2010).

Ukuran perusahaan adalah rata-rata total penjualan bersih untuk tahun yang bersangkutan sampai beberapa tahun. Dalam hal ini penjualan lebih besar dari pada biaya variabel dan biaya tetap, maka akan diperoleh jumlah pendapatan sebelum pajak. Sebaliknya jika penjualan lebih kecil dari pada biaya varibel dan biaya tetap maka perusahaan akan menderita kerugian menurut (Brigham \& Houston, 2006). Ukuran perusahaan dapat tercermin dari total aset, total penjualan, jumlah pekerja dan nilai tambah (Kusuma, 2005). Ukuran perusahaan dapat diukur dengan log natural terhadap total aset untuk menyederhanakan total aset yang jumlahnya sampai triliun.

Kinerja perusahaan dapat memberikan gambaran mengenai kondisi perusahaan saat ini maupun prospek dimasa depan. Kondisi kinerja perusahaan dapat dilihat dari laporan keuangan perusahaan. Ada beberapa cara dalam mengukur kinerja perusahaan salah satunya dengan melihat tingkat profitabilitasnya. Rasio profitabilitas ini untuk mengukur kemampuan perusahaan menghasilkan keuntungan pada tingkat penjualan, aset, dan modal saham tertentu (Hanafi, 2016, p. 42). Rasio profitabilitas dapat diukur dengan menggunakan Return On Asets (ROA) dan Return On Equity (ROE).

Skala ekonomi terjadi ketika biaya total ratarata jangka panjang menurun dan hasil produksi meningkat sedangkan yang disebut skala 
disekonomi adalah ketika biaya total rata-rata jangka panjang meningkat dan hasil produksi juga ikut meningkat (Mankiw, et al, 2014, p. 284).

\section{Kerangka Konseptual}

Berdasarkan penelitian terdahulu serta teori yang pendukung penelitian ini maka dikembangkan menjadi sebuah kerangka konseptual dapat terlihat pada gambar berikut:

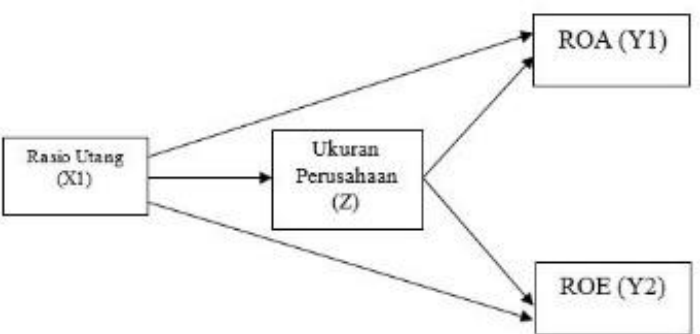

Gambar 1: Kerangka Konseptual

\section{Hipotesis Penelitian}

Berdasarkan kerangka konseptual dan teori pendukung maka peneliti mengajukan hipotesis sebagai berikut :

H1: rasio utang berpengaruh positif terhadap ROA.

$\mathrm{H} 2$ : rasio utang berpengaruh positif terhadap ROE.

H3: rasio utang berpengaruh positif terhadap ukuran perusahaan.

H4: ukuran perusahaan berpengaruh positif terhadap ROA.

H5: ukuran perusahaan berpengaruh positif terhadap ROE.

H6: rasio utang melalui ukuran perusahaan berpengaruh positif terhadap ROA

H7: rasio utang melalui ukuran perusahaan berpengaruh positif terhadap ROE.

\section{METODE PENELITIAN}

Penelitian ini termasuk jenis penelitian kausalitas dengan menggunakan pendekatan kuantitatif. Tujuan dari penelitian ini untuk menganalisis pengaruh antara variabel independen leverage/rasio utang dengan variabel dependen kinerja perusahaan yang diukur menggunakan rasio profitabilitas yaitu ROA dan ROE. Ukuran perusahaan dijadikan sebagai variabel intervening.Populasi dalam penelitian ini adalah seluruh perusahaan manufakur non migas yang terdaftar di Bursa Efek Indonesia dengan melihat laporan keuangan tahunan auditor dan Indonesia Capital Market Directory (ICMD) tahun 2015 sampai 2017.

Sampel dalam penelitian ini adalah perusahaan manufaktur non migas sektor industri makan dan minuman, industri tekstil dan pakaian jadi, industri kimia, farmasi dan obat tradisional, industri barang logam, serta industri alat angkutan.
Teknik pengambilan sampel menggunakan purposive sampling. Data yang diambil sesuai kriteria berikut :

1. Perusahaan manufaktur non migas sektor industri makan dan minuman, industri tekstil dan pakaian jadi, industri kimia, farmasi dan obat tradisional, industri barang logam, serta industri alat angkutan yang terdaftar di Bursa Efek Indonesia tahun 2015 - 2017.

2. Perusahaan manufaktur yang terdaftar secara kontinu dari tahun 2015 - 2017.

3. Perusahaan manufaktur yang mempunyai data laporan keuangan dari tahun 2015 -2017.

4. Perusahaan manufaktur yang memiliki nilai ROA dan ROE yang positif.

Tabel 4.1

Proses Pengambilan Sampel

\begin{tabular}{llll}
\hline No & \multicolumn{4}{c}{ Kriteria Sampel } & Ket \\
\hline $\mathbf{1}$ & $\begin{array}{l}\text { Seluruh perusahaan manufaktur non } \\
\text { migas dari beberapa sektor yang } \\
\text { dijadikan sampel penelitian yang } \\
\text { terdaftar di Bursa Efek Indonesia } \\
\text { periode 2015-2017 }\end{array}$ & $\mathbf{9 0}$ \\
\hline $\mathbf{2}$ & $\begin{array}{l}\text { Perusahaan yang delisting di Bursa Efek } \\
\text { Indonesia }\end{array}$ & $\mathbf{4}$ \\
\hline $\mathbf{3}$ & $\begin{array}{l}\text { Data laporan keuangan tidak tersedia } \\
\text { (Perusahaan baru terdaftar di BEI tahun }\end{array}$ & $\mathbf{2}$ \\
\hline $\mathbf{4}$ & $\begin{array}{l}\text { Perusahaan yang memiliki nilai ROA } \\
\text { dan ROE yang negatif }\end{array}$ & $\mathbf{3 2}$ \\
\hline
\end{tabular}

Jumlah Sampel Penelitian 52

\section{Sumber: Bursa Efek Indonesia (Data diolah 2019).}

Variabel independen pada penelitian ini adalah leverage/rasio utang yang diukur dari total utang terhadap total aset. Variabel dependen adalah kinerja perusahaan yang diukur melalui rasio profitabilitas yaitu ROA dan ROE. Ukuran perusahaan dalam penelitian ini dijadikan sebagai variabel intervening yang diukur melalui log natural terhadap total aset.

Teknik analisis yang tepat untuk model penelitian yang dibentuk dengan menggunakan variabel intervening atau mediating adalah analisis jalur (path analysis) karena analisis jalur memungkinkan untuk menguji hubungan langsung antar variabel maupun hubungan tidak langsung antar variabel (Ghozali \& Latan, 2015, p. 243). Pengujian efek dari variabel intervening dilakukan dengan 3 tahap menurut Baron \& Kenny (1986) antara lain :

1. Menguji pengaruh variabel independen terhadap variabel mediating atau intervening dan memiliki nilai signifikan. 
https://ejurnal.stimi-bjm.ac.id/index.php/JRIMK

2. Menguji variabel mediating atau intervening terhadap variabel dependen dan memiliki nilai signifikan.

3. Menguji pengaruh variabel independen dan variabel intervening atau mediating terhadap variabel dependen. Pada pengujian ini diharapkan variabel independen tidak memiliki pengaruh signifikan terhadap variabel dependen.

Analisis data menggunakan software statistik SmartPLS versi 3.2.8 dengan model evaluasi PLS dapat dilakukan dengan menilai outer model dan inner model. Pengujian hipotesis dapat dilihat dari nilai t-value dan nilai probabilitas. Pada penelitian ini menggunakan alpha 5\% atau 0.05.

\section{HASIL PENELITIAN DAN PEMBAHASAN}

\section{A. Evaluasi Model Pengukuran (outer model)}

\section{Tabel 1 : Loading Factor}

Sumber : Hasil Analisis SmartPLS (Data diolah 2019).

Hasil dari output analisis pada tabel 1 semua konstruk dengan indikator $\mathrm{X} 1, \mathrm{Y} 1, \mathrm{Y} 2$ dan $\mathrm{Z}$ mempunyai nilai loading factor yaitu 1,000 lebih besar dari persyaratan yang harus dipenuhi yaitu > 0,70 yang berarti semua konstruk indikator adalah benar serta memenuhi persyaratan dan dapat dilanjutkan pada proses selanjutnya.

Tabel 2 : Nilai Average Variance Extracted (AVE)

\begin{tabular}{lc}
\hline Variabel & $\begin{array}{c}\text { Average Variance } \\
\text { Extracted (AVE) }\end{array}$ \\
\hline ROA & 1,000 \\
\hline ROE & 1,000 \\
\hline Rasio & 1,000 \\
Utang & 1,000 \\
\hline Ukuran \\
Perusahaan
\end{tabular}

Sumber : Hasil Analisis SmartPLS (Data diolah 2019).

Pada tabel 2 nilai AVE yang dihasilkan dari semua nilai konstruk yaitu 1,000 diatas > 0,50 memenuhi persayarat validitas konvergen. Uji validitas dapat juga dilihat dari uji disciminant validity.

Tabel 3 : Nilai Cross Loading (Discriminant validity)

\begin{tabular}{ccccc}
\hline & ROA & ROE & $\begin{array}{c}\text { Rasio } \\
\text { Utang }\end{array}$ & $\begin{array}{c}\text { Ukuran } \\
\text { Perusahaan }\end{array}$ \\
\hline $\mathrm{X} 1$ & $-0,210$ & 0,225 & 1,000 & 0,139 \\
\hline $\mathrm{Y} 1$ & 1,000 & 0,760 & $-0,210$ & 0,100 \\
\hline
\end{tabular}

\begin{tabular}{ccccc}
\hline ROA & ROE & $\begin{array}{c}\text { Rasio } \\
\text { Utang }\end{array}$ & $\begin{array}{c}\text { Ukuran } \\
\text { Perusahaan }\end{array}$ \\
\hline Y2 & 0,760 & 1,000 & 0,225 & 0,074 \\
\hline $\mathrm{Z}$ & 0,100 & 0,074 & 0,139 & 1,000 \\
\hline
\end{tabular}

Sumber : Hasil Analisis SmartPLS (Data diolah 2019).

Nilai cross loading pada tabel 3 adalah 1,000 untuk masing-masing variabel yang berarti variabel pada penelitian ini semuanya mempunyai korelasi tertinggi pada dirinya sendiri dibandingkan dengan variabel lain. Nilai cross loading memenuhi persyaratan yaitu > 0,70 bahwa model benar dan syarat terpenuhi.

Tabel 4 : Nilai Akar Kuadrat AVE

\begin{tabular}{|c|c|c|c|c|}
\hline & ROA & ROE & $\begin{array}{l}\text { Rasio } \\
\text { Utang }\end{array}$ & $\begin{array}{c}\text { Ukuran } \\
\text { Perusahaan }\end{array}$ \\
\hline $\mathrm{X} 1$ & 1,000 & & & \\
\hline \multirow[t]{2}{*}{$\mathrm{Y} 1$} & 0,760 & 1,000 & & \\
\hline & ROA & ROE & $\begin{array}{c}\text { Ukuran } \\
\text { Perusahaan }\end{array}$ & $\begin{array}{l}\text { Rasio } \\
\text { Utang }\end{array}$ \\
\hline $\mathrm{X} 1$ & & & & 1.000 \\
\hline Y1 & 1.000 & & & \\
\hline $\mathrm{Y} 2$ & & 1.000 & & \\
\hline $\mathrm{Z}$ & & & 1.000 & \\
\hline Y2 & $-0,210$ & 0,225 & 1,000 & \\
\hline $\mathrm{Z}$ & 0,100 & 0,074 & 0,139 & 1,000 \\
\hline \multicolumn{5}{|c|}{$\begin{array}{l}\text { Pada tabel } 4 \text { terlihat bahwa nilai akar } \\
\text { kuadrat AVE lebih besar dibanding nilai korelasi } \\
\text { antar konstruk sehingga model dapat dikatakan } \\
\text { benar dan telah memenuhi persyarat dari uji } \\
\text { disciminant validity. }\end{array}$} \\
\hline \multicolumn{5}{|c|}{$\begin{array}{c}\text { Tabel } 5 \text { : Nilai cronbach's alpha dan composite } \\
\text { reliabity }\end{array}$} \\
\hline \multicolumn{2}{|c|}{ Variabel } & \multicolumn{2}{|c|}{$\begin{array}{cc}\text { Cronbach's } & C \\
\text { Alpha } & R\end{array}$} & $\begin{array}{l}\text { Composite } \\
\text { Reliability }\end{array}$ \\
\hline \multicolumn{2}{|c|}{$\mathrm{ROA}$} & 1,000 & \multicolumn{2}{|c|}{1,000} \\
\hline \multicolumn{2}{|c|}{ ROE } & 1,000 & \multicolumn{2}{|r|}{1,000} \\
\hline \multicolumn{2}{|c|}{ Rasio Utang } & 1,000 & \multicolumn{2}{|r|}{1,000} \\
\hline \multicolumn{2}{|c|}{$\begin{array}{c}\text { Ukuran } \\
\text { Perusahaan }\end{array}$} & 1,000 & \multicolumn{2}{|r|}{1,000} \\
\hline
\end{tabular}

Sumber : Hasil Analisis SmartPLS (Data diolah 2019).

Tabel 5 merupakan hasil dari analisis model dengan menggunakan smartPLS menunjukkan nilai cronbach's alpha yang dihasilkan 1,000 di atas > 0,70 dan nilai composite reliability yaitu 1,000 di atas > 0,70 memenuhi syarat. Pada model ini dapat disimpulkan bahwa nilai dari semua konstruk adalah reliabel atau memenuhi uji reliabilitas. 
B. Evaluasi Model Struktural (Inner Model)

Tabel 6 : Nilai $\mathbf{R}^{2}$ dan $\mathbf{R}^{2}$ Adjusted

\begin{tabular}{ccc}
\hline Variabel & $\begin{array}{c}\mathbf{R} \\
\text { Square }\end{array}$ & $\begin{array}{c}\text { R Square } \\
\text { Adjusted }\end{array}$ \\
\hline ROA & 0,061 & 0,049 \\
\hline ROE & 0,052 & 0,040 \\
\hline Ukuran Perusahaan & 0,019 & 0,013 \\
\hline
\end{tabular}

Sumber : : Hasil Analisis SmartPLS (Data diolah 2019).

Berdasarkan hasil analisis pada tabel 6 terlihat nilai R-square untuk variabel ROA sebesar 0,061 berarti model ini termasuk dalam kategori model lemah. Pengaruh variabel rasio utang (X1) dan ukuran perusahaan (Z) terhadap ROA (Y1) adalah $6,1 \%$ dan sisanya $93,9 \%$ dipengaruhi oleh variabel lain diluar model penelitian ini.

Nilai R-square untuk variabel ROE sebesar 0,063 termasuk dalam kategori model lemah. Pengaruh variabel rasio utang (X1) dan ukuran perusahaan (Z) terhadap ROE (Y2) adalah 5,2\% dan sisanya $94,8 \%$ dipengaruhi oleh variabel lain diluar model penelitian ini.

Nilai R-square untuk variabel ukuran perusahaan sebesar 0,019 termasuk dalam kategori model lemah. Pengaruh variabel rasio utang (X1) terhadap ukuran perusahaan $(\mathrm{Z})$ adalah $1,9 \%$ dan sisanya $98,1 \%$ dipengaruhi oleh variabel lain diluar model penelitian ini.

\section{Hasil Uji Hipotesis}

Tabel 7 : Hasil pengujian hipotesis

\begin{tabular}{cccccc}
\hline Keterangan & $\begin{array}{c}\text { Original } \\
\text { Sample } \\
(\mathbf{O})\end{array}$ & $\begin{array}{c}\text { Sample } \\
\text { Mean } \\
(\mathbf{M})\end{array}$ & $\begin{array}{c}\text { Standard } \\
\text { Deviation } \\
(\text { STDEV) }\end{array}$ & $\begin{array}{c}\text { T Statistics } \\
(\mid \mathbf{O} / \text { STDEV|) }\end{array}$ & $\begin{array}{c}\boldsymbol{P} \\
\text { Values }\end{array}$ \\
\hline $\begin{array}{c}\text { Rasio Utang } \\
\rightarrow \text { ROA }\end{array}$ & $-0,228$ & $-0,241$ & 0,095 & 2,392 & $0,008^{*}$ \\
\hline $\begin{array}{c}\text { Rasio Utang } \\
\rightarrow \text { ROE }\end{array}$ & 0,219 & 0,211 & 0,095 & 2,295 & $0,011^{*}$ \\
\hline $\begin{array}{c}\text { Rasio Utang } \\
\rightarrow \text { Ukuran } \\
\text { Perusahaan }\end{array}$ & 0,139 & 0,142 & 0,071 & 1,966 & $0,025^{*}$ \\
\hline $\begin{array}{c}\text { Ukuran } \\
\text { Perusahaan } \\
\rightarrow \text { ROA }\end{array}$ & 0,131 & 0,137 & 0,054 & 2,423 & $0,008^{*}$ \\
\hline $\begin{array}{c}\text { Ukuran } \\
\text { Perusahaan } \\
\rightarrow \text { ROE }\end{array}$ & 0,044 & 0,051 & 0,053 & 0,827 & 0,204 \\
\hline
\end{tabular}

\section{Sumber : Hasil Analisis SmartPLS (data diolah} 2019).

Hasil pengujian hipotesis diketahui nilai tstatistik sebesar 2,392 yaitu nilai t-statistik > 1,96 dan nilai p-value sebesar 0,008 lebih kecil $<0,05$ sehingga hipotesis H1 diterima. Hasil dari pengujian hipotesis diketahui rasio utang berpengaruh signifikan terhadap ROA. Nilai koefisien dari hasil pengujian statistik adalah $-0,228$ berarti menunjukkan adanya hubungan negatif antara rasio utang dengan ROA perusahaan. Keutungan yang dihasilkan perusahaan digunakan untuk membayar bunga dan pokok pinjaman sehingga dapat mengurangi laba dan menurunkan kinerja perusahaan. Hal ini menjelaskan bahwa penambahan $1 \%$ utang dapat mengurangi laba yang dihasilkan oleh perusahaan sebesar -0,228 atau $22,8 \%$. Hasil penelitian ini didukung oleh penelitian sebelumnya yang dilakukan oleh Hasan, et al (2014), Khan (2012) dan Siddik et al (2016).

Hasil pengujian hipotesis diketahui nilai tstatistik sebesar 2,295 yaitu nilai t-statistik >1,96 dan nilai p-value sebesar 0,011 lebih kecil < 0,05 sehingga hipotesis $\mathrm{H} 2$ diterima. Hasil dari pengujian hipotesis diketahui rasio utang berpengaruh signifikan terhadap ROE. Nilai koefisien dari hasil pengujian statistik adalah 0,219 berarti menunjukkan adanya hubungan positif antara rasio utang dengan ROE perusahaan. Hal ini menjelaskan bahwa penambahan $1 \%$ utang dapat meningkatkan laba yang dihasilkan oleh perusahaan sebesar 0,219 atau $21,9 \%$. Ketika rasio utang tinggi berarti perusahaan menggunakan utang yang banyak. Bunga yang ditimbulkan oleh utang tersebut juga akan meningkat dan bunga tersebut dapat mengurangi pembayaran pajak perusahaan sehingga laba bersih perusahaan bertambah. Penggunaan utang yang tinggi dapat meningkatkan profitabilitas (Hanafi, 2016, p. 41). Hasil penelitian ini didukung oleh penelitian sebelumnya yang dilakukan oleh Khan (2012) dan Siddik et al (2016)

Hasil pengujian hipotesis diketahui nilai tstatistik sebesar 1,966 yaitu nilai t-statistik > 1,96 dan nilai p-value sebesar 0,025 lebih kecil $<0,05$

$\boldsymbol{P}$ sehingga hipotesis H3 diterima. Hasil dari pengujian hipotesis diketahui rasio utang serpengaruh signifikan terhadap ukuran perusahaan. Nilai koefisien menunjukkan arah yang $011^{*}$ positif yaitu 0,139 yang berarti adanya hubungan positif antara rasio utang dengan ukuran $025^{*}$ perusahaan. Hal ini menjelaskan bahwa penambahan $1 \%$ utang dapat meningkatkan aset perusahaan sebesar 0,139 atau $13,9 \%$. Utang dapat meningkatkan aset perusahaan. Penggunaan utang oleh perusahan dapat meningkatkan modal ${ }^{204}$ perusahaan, modal tersebut nantinya dapat dikelola untuk membeli aset sehingga aset perusahaan dapat bertambah. Besar atau kecilnya ukuran perusahaan dapat dilihat dari total aset yang dimiliki. Perusahaan yang besar yaitu perusahaan yang memiliki banyak aset yang mana aset tersebut memiliki manfaat di masa yang akan datang. Aset yang dimiliki perusahaan ada yang sifatnya berwujud dan ada juga tidak berwujud. Hasil pengujian statistik pada penelitian ini memenuhi 
https://ejurnal.stimi-bjm.ac.id/index.php/JRIMK

tahapan untuk menguji efek variabel mediating atau intervening.

Hasil pengujian hipotesis diketahui nilai tstatistik sebesar 2,423 yaitu nilai t-statistik >1,96 dan nilai p-value sebesar 0,008 lebih kecil < 0,05 sehingga hipotesis H4 diterima. Hasil dari pengujian hipotesis diketahui ukuran perusahaan berpengaruh signifikan terhadap kinerja perusahaan yang diukur melalui rasio keuangan ROA. Nilai koefisien dari hasil pengujian statistik adalah 0.131 berarti menunjukkan arah yang positif antara ukuran perusahaan dengan ROA perusahaan. Hal ini menjelaskan bahwa ukuran perusahaan yang bertambah sebanyak $1 \%$ yang diukur melalui total aset perusahaan dapat meningkatkan laba perusahaan sebesar $13,1 \%$. Ukuran perusahaan yang bertambah sebanyak $1 \%$ yang diukur melalui total aset perusahaan dapat meningkatkan laba perusahaan sebesar $13,1 \%$. Perusahaan yang besar memiliki banyak keuntungan, dilihat dari hasil penelitian yang berpengaruh terhadap ROA menandakan perusahaan mampu menghasilkan laba bersih dari penggunaan aset yang dikelola dengan baik. Perusahaan dapat mengoptimalkan penggunaan aset yang dimiliki baik diversifikasi produk maupun investasi sehingga berdampak pada laba bersih yang dihasilkan. Hasil ini mendukung teori skala ekonomi. Hasil penelitian ini didukung oleh penelitian sebelumnya yang dilakukan oleh Hasan, et al (2014), Tifow dan Sayilir (2015).

Hasil pengujian hipotesis diketahui nilai tstatistik sebesar 0,827 yaitu nilai t-statistik $<1,96$ dan nilai p-value sebesar 0,204 lebih kecil > 0,05 sehingga hipotesis H5 ditolak. Hasil dari pengujian hipotesis diketahui ukuran perusahaan tidak berpengaruh terhadap ROE. Hasil penelitian ini didukung oleh penelitian sebelumnya yang dilakukan oleh Hasan, et al (2014), Tifow dan Sayilir (2015). Hasil penelitian yang tidak berpengaruh menjelaskan bahwa besarnya ukuran perusahaan bukan jaminan bahwa perusahaan tersebut memiliki profitabilitas yang tinggi. Dilihat dari tidak berpengaruhnya terhadap ROE mengindikasikan adanya faktor lain yang harus diperhatikan bagaimana manajemen mengelola ekuitasnya dalam mendanai biaya operasional yang ditimbulkan oleh banyaknya aset yang dimiliki sehingga tidak berpengaruh pada peningkatan laba perusahaan. ROE juga mengukur seberapa efektif manajemen perusahaan mengelola ekuitasnya. ROE sangat penting untuk calon investor karena seberapa besar ukuran perusahaan mampu memuaskan pemegang sahamnya.
Tabel 8 : Hasil pengujian hipotesis mediasi

\begin{tabular}{|c|c|c|c|c|c|}
\hline Keterangan & $\begin{array}{c}\text { Original } \\
\text { Sample } \\
\text { (O) }\end{array}$ & $\begin{array}{c}\text { Sample } \\
\text { Mean } \\
\text { (M) }\end{array}$ & $\begin{array}{c}\text { Standard } \\
\text { Deviation } \\
\text { (STDE } \\
\text { V) }\end{array}$ & $\begin{array}{c}T \\
\text { Statis } \\
\text { tics } \\
(\mid \mathbf{O} / \mathbf{S} \\
\text { TDE } \\
\mathbf{V |})\end{array}$ & $P$ Values \\
\hline $\begin{array}{l}\text { Rasio Utang } \rightarrow \text { Ukuran } \\
\text { Perusahaan } \rightarrow \text { ROA }\end{array}$ & 0,018 & 0,020 & 0,014 & 1,304 & 0,096 \\
\hline $\begin{array}{l}\text { Rasio Utang } \rightarrow \text { Ukuran } \\
\text { Perusahaan } \rightarrow \text { ROE }\end{array}$ & 0,006 & 0,007 & 0,010 & 0,640 & 0,261 \\
\hline
\end{tabular}

Sumber : Hasil Analisis SmartPLS (data diolah 2019)

Hasil pengujian hipotesis diketahui nilai tstatistik sebesar 1,304 yaitu nilai t-statistik $<1,96$ dan nilai p-value sebesar 0,096 lebih besar > 0,05 sehingga hipotesis H6 ditolak. Hasil penelitian ini tidak sejalan dengan hipotesis yang diajukan. Rasio utang yang tidak berpengaruh terhadap ROA perusahaan melalui ukuran perusahaan mengindikasikan bahwa manajer perusahaan mampu memaksimalkan aset yang dimiliki dalam menghasilkan laba bersih. Dengan banyaknya aset manajer perusahaan mampu memanfaatkan aset tersebut sehingga menghasilkan keuntungan bagi perusahaan. Penggunaan utang bukan faktor penting dalam menghasilkan laba pada perusahaan yang besar tetapi bagaimana manajemen mengelola aset yang dimiliki. Pengaruh berjenjang yang berawal dari kebijakan perusahaan dalam menentukan sumber pendanaan eksternal yaitu utang dari kreditur dapat digunakan dalam menambah aset perusahaan baik yang berwujud maupun tidak, dan aset tersebut dimanfaatkan secara efektif dalam menghasilkan keuntungan bagi perusahaan.

Hasil pengujian hipotesis diketahui nilai tstatistik sebesar 0,640 yaitu nilai t-statistik $<1,96$ dan nilai p-value sebesar 0,261 lebih besar > 0,05 sehingga hipotesis $\mathrm{H} 7$ ditolak. Hasil dari pengujian hipotesis diketahui bahwa secara tidak langsung rasio utang tidak berpengaruh signifikan terhadap kinerja perusahaan melalui ukuran perusahaan. Hasil penelitian ini rasio utang tidak berpengaruh terhadap ROE melalui ukuran perusahaan tidak sejalan dengan hipotesis yang diajukan. Perusahaan yang dijadikan sampel dalam penelitian memiliki rata-rata ROA yang kecil. Jika ROA lebih kecil dari tingkat bunga, maka keperluan dana sebaiknya diambil dari penambahan modal sendiri baik melalui emisi saham maupun laba ditahan sebab akan meningatkan ROE (Fachrudin, 2011). Perusahaan besar cenderung memiliki banyak modal, perputaran uang yang lebih serta kapitalisasi pasar yang baik mampu meningkatkan kinerja perusahaan. Laba yang dihasilkan dapat digunakan untuk menambah modal yaitu dengan laba ditahan maupun membagi ke pemegang saham. Penggunaan utang bukan faktor yang harus diperhitungkan dalam meningkatkan kinerja 
perusahaan ketika perusahaan mempunyai total aset yang banyak.

\section{Implikasi Teoritis}

Kinerja perusahaan yang baik merupakan tujuan dari setiap perusahaan. Beberapa cara digunakan untuk meningkatkan kinerja perusahaan mulai dari kebijakan dalam pemilihan pendanaan untuk mendanai kegiatan operasional serta memanfaatkan sumber daya yang dimiliki oleh perusahaan dengan lebih efektif.

Berdasarkan pengujian hipotesis 1 memberikan hasil bahwa rasio utang berpengaruh negatif dan signifikan terhadap ROA. Hasil ini mendukung teori packing order bahwa perusahaan yang mempunyai keuntungan yang tinggi menggunakan utang yang rendah. Hal ini dapat menjelaskan bahwa perusahaan harus lebih berhatihati dalam memilih utang sebagai sumber pendanaan karena utang mempunyai beban tetap yang harus dibayar. Arah yang negatif mengindikasikan bahwa utang dapat menurunkan kinerja perusahaan sebab laba yang dihasilkan oleh perusahaan digunakan untuk membayar bunga dan pokok pinjam sehingga menurunkan profitabilitas perusahaan. Hasil penelitian ini didukung oleh penelitian sebelumnya yang dilakukan oleh Hasan, et al (2014), Khan (2012) dan Siddik et al (2016).

Berdasarkan pengujian hipotesis 2 memberikan hasil rasio utang berpengaruh positif dan signifikan terhadap ROE. Hasil penelitian ini mendukung teori trade-off bahwa jika struktur modal pada perusahaan belum mencapai titik maksimum maka setiap penambahan utang akan meningkatkan kinerja perusahaan. Penggunaan utang yang tinggi dapat meningkatkan profitabilitas (Hanafi, 2016, p. 41). Bunga yang ditimbulkan oleh utang dapat mengurangi pembayaran pajak perusahaan sehingga berpengaruh pada keuntungan perusahaan. ROE yang baik berarti manajemen perusahaan dapat mengelola dana perusahaan dengan efektif. Hasil penelitian ini didukung oleh penelitian sebelumnya yang dilakukan oleh Khan (2012) dan Siddik et al (2016).

Berdasarkan pengujian hipotesis 3 memberikan hasil rasio utang berpengaruh positif dan signifikan terhadap ukuran perusahaan. Hasil ini sejalan dengan persamaan dasar akuntansi bahwa aset terdiri atas utang dan modal. Adanya pengaruh positif antara rasio utang dengan ukuran perusahaan menunjukkan bahwa perusahaan masih harus mempertimbangan penggunaan utang. Penggunaan utang oleh perusahaan dapat meningkatkan modal perusahaan dan modal tersebut dapat dipergunakan dalam pembelian aset yang menguntungkan sehingga aset perusahaan juga dapat meningkat. Sesuai persamaan dasar akuntasi bahwa aset terdiri atas utang dan modal dapat diartikan penambahan utang dapat meningkatkan aset perusahaan. Hasil pengujian statistik pada penelitian ini juga memenuhi tahapan dari penguji efek variabel mediating atau intervening.

Hasil pengujian hipotesis 4 menunjukkan hasil bahwa ukuran perusahan berpengaruh positif dan signifikan terhadap kinerja perusahaan melalui rasio profitabilitas yaitu ROA. Hasil penelitian yang memiliki pengaruh dapat menjelaskan bahwa manajemen perusahaan dapat mengoptimalkan aset yang dimiliki baik dalam diversifikasi produk, investasi maupun ekspansi sehingga berdampak pada laba bersih yang dihasilkan. Perusahaan besar lebih mudah mengembangkan usahanya dan tidak bergantung pada satu usaha saja sehingga terjadi diversifikasi. Hasil ini mendukung teori skala ekonomi bila skala ekonomi tercapai perusahaan yang terdiversifikasi berpotensi lebih profitable dari perusahaan kecil yang berspesialisasi (Kusuma, 2005). Hasil penelitian ini didukung oleh penelitian sebelumnya yang dilakukan oleh Aziz \& Abbas (2019), Zeitun \& Tian (2017), dan Bokhari \& Khan (2013).

Hasil dari pengujian hipotesis 4 juga memenuhi dari syarat pengujian efek mediasi sehingga ukuran perusahaan dapat dikatakan sebagai variabel intervening atau mediasi. Terlihat dari hasil pegujian hipotesis 6 pengujian efek mediasi ukuran perusahaan mampu memediasi pengaruh rasio utang terhadap ROA secara penuh atau mediasi penuh.

\section{E. Implikasi Manajerial}

Hasil penelitian ini memberikan implikasi manajerial bahwa rasio utang berpengaruh terhadap kinerja perusahaan. Penggunaan sumber pendanaan eksternal berupa utang dapat mengurangi kinerja perusahaan sebab laba yang dihasilkan digunakan untuk membayar kewajiban perusahaan baik pokok pinjaman maupun bunga yang ditimbulkan dari utang tersebut sehingga dapat menurunkan profitabilitas perusahaan. Selain itu, sesuai dengan teori utang dapat meningkatkan profitabiltas sebab bunga yang ditimbulkan oleh utang dapat mengurangi pembayaran pajak perusahaan.

Rasio utang berpengaruh terhadap ukuran perusahaan. Hasil ini dapat menejelaskan bahwa manajemen perusahaan juga dapat menggunakan utang dalam meningkatkan modal perusahaan. Modal perusahaan selain dimanfaatkan dalam mendanai operasional perusahaan juga dapat digunakan untuk membeli aset yang memiliki manfaat di masa yang akan datang sehingga aset perusahaan juga bertambah. Aset yang dimiliki 
perusahaan ada yang sifatnya berwujud dan ada juga tidak berwujud.

Ukuran perusahaan berpengaruh terhadap ROA perusahaan. Hasil ini menjelaskan perusahaan yang besar memiliki banyak keuntungan. Manajemen perusahaan mampu menghasilkan laba bersih dari penggunaan aset yang dimiliki perusahaan. Perusahaan dapat mengoptimalkan penggunaan aset yang dimiliki baik diversifikasi produk maupun investasi sehingga berdampak pada laba bersih yang dihasilkan. Perusahaan manufaktur yang dijadikan sampel penelitian merupakan perusahaan memiliki banyak aset dan produk yang dihasilkan juga sudah terkenal di masyarakat. Manajer harus mengoptimalkan aset yang dimiliki perusahaan berdampak pada kinerja perusahaan.

\section{PENUTUP}

\section{Simpulan}

Penelitian ini bertujuan untuk menganalisis pengaruh rasio utang terhadap kinerja perusahaan yang diukur melalui rasio profitabiltas yaitu ROA dan ROE. Ukuran perusahaan dalam penelitian ini dijadikan sebagai variabel intervening atau mediating yang dapat dilalui oleh rasio utang dalam mempengaruhi kinerja perusahaan. Berdasarkan pengujian secara statistik menghasilkan beberapa temuan yang dapat disimpulkan sebagai berikut:

a. Rasio utang berpengaruh negatif dan signifikan terhadap ROA perusahaan. Hasil ini sesuai dengan teori packing order bahwa perusahaan yang mempunyai keuntungan yang besar menggunakan utang yang sedikit.

b. Rasio utang berpengaruh positif dan signifikan terhadap ROE perusahaaan. Hasil ini mendukung teori trade off yaitu sebelum mencapai titik maksimum penambahan utang dapat meningkatkan pendapatan perusahaan sehingga kinerja perusahaan meningkat.

c. Rasio utang berpengaruh positif dan signifikan terhadap ukuran perusahaan yang diukur dengan total aset. Penggunaan utang oleh perusahaan dapat meningkatkan aset perusahaan. Utang tersebut nantinya akan digunakan untuk membeli aset perusahaan sehingga aset perusahaan bertambah. Hasil ini memenuhi syarat dari pengujianefek mediasi bahwa variabel independen berpegaruh signifikan terhadap variabel intervening atau mediating.

d. Ukuran perusahaan berpengaruh positif dan signifikan terhadap kinerja perusahaan yaitu ROA. Hasil ini sesuai dengan teori skala ekonomi. Bila skala ekonomi tercapai perusahaan yang terdiversifikasi berpotensi lebih profitable dari perusahaan kecil yang berspesialisasi (Kusuma, 2005). Hasil ini memenuhi syarat dari pengujian efek mediasi bahwa variabel intervening atau mediating berpengaruh signifikan terhadap variabel dependen.

e. Ukuran perusahaan tidak berpengaruh terhadap kinerja perusahaan yaitu ROE. Perusahaan yang mempunyai aset yang banyak tidak menjamin keutungan. Manajemen harus memperhitungkan dalam mengelola ekuitasnya untuk mendanai biaya operasional yang ditimbulkan oleh banyaknya aset yang dimiliki sehingga tidak berpengaruh pada peningkatan laba perusahaan.

f. Rasio utang tidak berpengaruh terhadap kinerja perusahaan secara tidak langsung melalui ukuran perusahaan. Hasil ini mendukung teori packing order karena teori ini merupakan urutan dari pemilihan pendanaan. Hal ini memungkinkan perusahaan lebih memilih mengoptimalkan penggunaan aset dan modal sendiri yang dimiliki untuk meningkatkan kinerja perusahaan.

g. Penelitian ini menghasilkan temuan ukuran perusahaan mampu memediasi secara penuh pengaruh rasio utang terhadap kinerja perusahaan yang diukur melalui rasio profitabilitas yaitu ROA.

\section{Saran}

Pada penelitian ini dengan melihat hasil dari analisis serta pembahasan yang telah dijelaskan maka terdapat beberapa saran antara lain:

a. Kepada manajemen perusahaan diharapkan mampu mengoptimalkan penggunaan utang sehingga utang yang digunakan perusahaan sebagai salah satu sumber pendanaan tidak hanya menimbulkan beban tetapi juga menghasilkan pengembalian yang tinggi kepada perusahaan.

b. Bagi perusahaan yang memiliki aset yang banyak, manajemen diharapkan mampu mengoptimalkan aset yang dimiliki untuk menghasilkan laba karena ketika perusahaan memiliki total aset yang banyak pemilihan sumber pendanaan ekternal yaitu utang tidak lagi terlalu berdampak pada meningkatnya kinerja perusahaan.

\section{DAFTAR PUSTAKA}

Azeez, D. A. (2015). Corporate Governance and Firm Performance: Evidence from Sri Lanka. Journal of Finance and Bank Management.

Aziz, S., \& Abbas, U. (2019). Effect of Debt Financing on Firm Performance: A Study 
on Non-Financial Sector of Pakistan. Open Journal of Economics and Commerce.

Baron, R. M., \& Kenny, D. A. (1986). The Moderator-Mediator Variabel Distinction in Social Psychological Research: Conceptual, Strategic, and Statistical Considerations. Journal of Personality and Social Psychology, Vol 15, No.6, 11731182.

Bokhari, H. W., \& Khan, M. A. (2013). The Impact of Capital Structure on Firm's Performance ( A case of Non-Financial Sector of Pakistan). European Journal of Business and Management.

BPS. (2019). Badan Pusat Statistik. Diambil kembali dari www.bps.go.id

Brigham, E. F., \& Houston, J. F. (2006). Fundamentals of Financial Management, Edisi 10. Jakarta: Salemba Empat.

Fachrudin, K. A. (2011). Analisis Pengaruh Struktur Modal, Ukuran Perusahaan, dan Agency Cost Terhadap Kinerja Perusahaan. JURNAL AKUNTANSI DAN KEUANGAN, VOL. 13 No. 1, 37-46.

Ghozali, I., \& Latan, H. (2015). Partial Least Squares Konsep, Teknik dan Aplikasi mengunakan SmartPLS 3.0. Semarang: Badan Penerbit - Undip.

Hanafi, M. M. (2016). Manajemen Keuangan. Yogyakarta: BPFE-Yogyakarta.

Hasan, M. B., Ahsan, A. F., Rahaman, M. A., \& Alam, M. N. (2014). Influence of Capital Structure on Firm Performance: Evidence from. Canadian Center of Science and Education.

Imadudin, Z., Swandari, F., \& Redawati. (2014). Pengaruh Struktur Modal Terhadap Kinerja Perusahaan. Jurnal Wawasan Manajemen.

Khan, A. G. (2012). The Relationship of Capital Structure Decisions with Firm Performance: A Study of The Engineering Sector of Pakistan. Macrothink Institute.
Kusuma, H. (2005). Size Perusahaan dan Profitabilitas : Kajian Empiris Terhadap Perusahaan Manufaktur yang Terdaftar di Bursa Efek Jakarta. Jurnal Ekonomi Pembangunan Vol. 10, Hal: 81-93.

Mankiw, N. G., Quah, E., \& Wilson, P. (2014). Pengantar Ekonomi Mikro. Jakarta: Salemba Empat.

Siddik, M. N., Kabiraj, S., \& Joghee, S. (2016). Impacts of Capital Structure on Performance of Banks. Int. J. Financial Study.

Sudiyatno, B. (2010). Peran kinerja Perusahaan Dalam Menentukan Pengaruh Faktor Fundamental Makroekonomi, Risiko Sistematis, dan Kebijakan Perusahaan Terhadap Nilai Perusahaan. Disertasi.

Tifow, A. A., \& Sayilir, O. (2015). Capital Structure and Firm Performance : An Analysis of Manufacturing Firms in Turkey. Eurasian Journal of Business and Management.

William, J., \& Sanjaya, R. (2017). Faktor-Faktor Yang Mempengaruhi Kinerja Perusahaan Pada Perusahaan Yang Terdaftar DI Bursa Efek Indonesia. Jurnal Bisnis dan Akuntansi, ISSN: 1410 - 9875, Hlm. 152162.

Zeitun, R., \& Tian, G. (2007). Capital structure and corporate performance: evidence from Jordan. Australasian Accounting, Business and Finance Journal.

\section{Profil penulis}

Muhammad Fathoni, Mahasiswa Program Studi Magister Manajemen, Fakultas Ekonomi dan Bisnis,Universitas Lambung Mangkurat.

Banjarmasin

Jl. Brigjen H. Hasan Basri, Pangeran, Kec. Banjarmasin Utara, Kota Banjarmasin, Kalimantan Selatan 70123, Indonesia

Email : fathoni.muh51@gmail.com 